\title{
Effect of Fucoidan on Angiogenesis and Gene Expression in Human Umbilical Vein Endothelial Cells
}

\author{
Ho Park ${ }^{1}$, Beom-Su Kim ${ }^{2}$ \\ ${ }^{1}$ Department of Clinical Laboratory Science, Wonkwang Health Science University, Iksan, Korea \\ ${ }^{2}$ Carbon Nano Convergence Technology Center for Next Generation Engineers, Chonbuk National University, Jeonju, Korea
}

\section{후코이단이 혈관 내피세포의 신생혈관 생성 효과 및 관련 유전자의 발현에 미치는 영향}

박 오 $^{1}$, 김범수 $^{2}$

${ }^{1}$ 원광보건대학교 임상병리학과, ${ }^{2}$ 전북대학교 탄소기반 나노 융합 응용기술 차세대 공학연구자 육성사업단

\begin{abstract}
Angiogenesis is a process including members of the angiogenic factors. In particular, fibroblast growth factor 2 (FGF2) is considered the most potent angiogenic factor because it promotes cell proliferation and tube formation. A recent study reported that fucoidan derived from marine plant potentiated FGF-2 induced tube formation in human endothelial cells. On the other hand, the molecular mechanisms involved in the angiogenic activity of fucoidan and FGF2 are unknown. In this study, a fucoidan treatment promoted angiogenesis induced by FGF2. The effects of fucoidan on FGF2-induced angiogenesis were confirmed by a proliferation assay using a CellTiter96 Aqueous One solution after a treatment with fucoidan and FGF2. The tube formation and wound healing assay for the angiogenic activity were also confirmed. Reverse transcription PCR showed a change in the mRNA of vascular endothelial growth factor-A (VEGF-A), intercellular adhesion molecule-1 (ICAM-1), matrix metallopeptidase9 (MMP9), and the signal transducer and activator of transcription3 (STAT3). In summary, the Fucoidan/FGF2 treatment induced an increase in cell proliferation, improved the tube formation and wound healing activity, and altered the STAT3, VEGF-A, ICAM-1, and MMP9 mRNA expression levels. Further research will be needed to provide a scientific explanation in terms of cell-signaling and confirm the present findings.
\end{abstract}

Key words: Angiogenesis, FGF2, Fucoidan, Human umbilical vein endothelial cells

This is an Open Access article distributed under the terms of the Creative Commons Attribution Non-Commercial License (http://creativecommons.org/licenses/by-nc/4.0) which permits unrestricted non-commercial use, distribution, and reproduction in any medium, provided the original work is properly cited.

Copyright ( 2017 The Korean Society for Clinical Laboratory Science. All rights reserved.
Corresponding author: Ho Park

Department of Clinical Laboratory Science, Wonkwang Health Science University, 514 Iksandae-ro, Iksan 54538, Korea

Tel: 82-63-840-1214

Fax: 82-63-840-1219

E-mail: bacoya@naver.com

Received: October 27, 2017

Revised $1^{\text {st. }}$ : December 1, 2017

Revised $2^{\text {nd. }}$ : December 6, 2017

Accepted: December 6, 2017

\section{서 론}

신생혈관생성은 기존 혈관들로부터 새로운 혈관이 형성되는 과정으로, 이는 배아 발생, 상처치유, 염증 그리고 암 성장을 포 함하는 다양한 생리학적 및 병리학적 조건에서 중요한 역할을 한다[1]. 신생혈관생성과정은 여러인자들에 의해 조절되는데 [2], 이러한 신생혈관생성이 정상적으로 조절되지 못하면 암, 류
마티스성 관절염, 당뇨병성 망막증 등 여러 가지 질환들이 야기 되기 때문에 중요한 연구 대상이다. 또한 신생혈관생성이 일어 나기 위해서는 vascular endothelial growth factor-A (VEGF-A), transforming growth factor alpha (TGF- $\alpha$ ), platelet derived growth factors (PDGF), tumor necrosis factor alpha (TNF-alpha) 등 다양한 신생혈관인자가 관여하기 때문에 신생 혈관생성 인자의 특성을 연구하는 것 역시 중요한 연구 대상이 
된다. 그 중 fibroblast growth factor2 (FGF2)는 내피세포의 성장을 촉진할 뿐만 아니라, 내피세포의 물리적 조직에도 관여 하기 때문에 다른 신생혈관생성 인자 못지 않게 중요한 인자로 여겨진다[3].

최근 연구에 따르면 신생혈관생성에 관한 연구에서는 후코 이단(Fucoidan)이 FGF2에 의해 유도되는 신생혈관생성의 효 과를 증가시킨다고 하였다[4]. 이는, fucoidan이 학문상의 생리 학적, 생화학적 연구 대상일 뿐만 아니라, 다양한 질병과의 관련 성도 가지고 있음을 나타낸다. Fucoidan은 일반적으로 갈조류 에서 분리될 수 있는 fucose-enriched sulfated polysaccharides 이다[5]. 비록 신생혈관생성 에 관한 연구에서 fucoidan이 신생 혈관생성 증진 효과[6,7]와 이에 반대적인 신생혈관생성 억제 효과를 가지고 있다는 상반되는 연구결과들이 보고된 바 있지 만[8], 이러한 신생혈관생성 활성 연구 및 기본적인 메커니즘에 대한 연구가 부족한 실정이다. 이에 본 연구에서는, fucoidan 이 인간 제대혈 유래 혈관 내피세포인 human umbilical vein endothelial cells (HUVECs) 세포에 미치는 영향에 대하여 조 사하였다. 특히 신생혈관생성이라는 과정이 다양한 신생혈관 생성 인자와 이와 관련된 수용체가 결합함으로써 일어난다는 부분에 초점을 두어, FGF2와 fucoidan을 함께 처리함으로써 발생하는 관형성 및 세포이동 등의 연구와 이의 과정에서 변화 되는 유전자의 분자적 수준의 발현을 확인하고자 하였다.

\section{재료 및 방법}

\section{1. 재료}

본 연구에서는, 갈색 해조류(Laminaria Japonica)에서 추출 된 3,300 Da 100,000 Da의 분자량으로 $61.5 \%$ 의 다당류와 $23.5 \%$ 의 sulfate로 구성된 후코이단을 해원바이오텍(Haewon Biotech, Seoul, Korea)에서 공급받아 사용하였다.

\section{2. 세포배양}

본 연구에서는 불멸화 인간 제대혈 유래의 혈관내피세포 (immortalized HUVECs) American Type Culture Collection (ATCC, Rockville, MD, USA)에서 구입하였으며, 10\% FBS (Gibco, CA, USA)가 포함된 Dulbecco's Modified Eagle Medium (DMEM, Gibco)에 antibiotics (Gibco)을 첨가한 배지를 이용 하여 $37^{\circ} \mathrm{C}, 5 \% \mathrm{CO}_{2}$ 배양기에서 배양하였다.

\section{3. 세포 증식율 측정}

Fucoidan과 FGF2 (Sigma-Aldrich, MO, USA)을 처리했을
때의 성장률을 측정하였다. HUVECs을 96 well plate에 $5 \times 10^{3}$ cells/well 부착시키고, 24 시간 배양시킨 후, $10 \mathrm{ng} / \mathrm{mL}$ 의 FGF2과 $1 \mu \mathrm{g} / \mathrm{mL}$ 그리고 $10 \mu \mathrm{g} / \mathrm{mL}$ 의 fucoidan을 처리하였 다[4]. FGF2와 fucoidan이 처리된 세포를 $37^{\circ} \mathrm{C}, 5 \% \mathrm{CO}_{2}$ 배양 기에서 배양하고, 6 일 경과한 시점에서 MTS assay를 통해 성장 률을 확인하였다.

\section{Matrigel을 이용한 혈관튜브 형성 측정}

Matrigel을 이용한 튜브 형성 정도의 평가는 신생혈관생성의 효과를 확인하기 위해 방법으로 많이 사용된다[4,9]. 이에 본 연 구에서 fucoidan의 angiogenic 효과를 평가하기 위하여 혈관 튜브 형성률을 평가하였다. 실험을 위하여 $4^{\circ} \mathrm{C}$ 에서 미리 녹여 둔 Matrigel (BD Biosciences, New Bedford, MA, USA)을 취 하여 96 well plate에 loading하고, 이를 $37^{\circ} \mathrm{C}, 5 \% \mathrm{CO}_{2}$ incubator에서 한 시간 동안 incubation하여 겔로 굳혔다. 이후 세 포를 $3 \times 10^{4} \mathrm{cells} / \mathrm{well}$ 의 농도로 Matrigel 위에 접종하여 배양 하였으며, 이때 FGF2 $(10 \mathrm{ng} / \mathrm{mL})$ 및 fucoidan $(1 \mu \mathrm{g} / \mathrm{mL})$ 을 처 리하고 24 시간 경과 후, 현미경을 이용하여 이미지를 획득하였다.

\section{Wound healing assay}

혈관 형성에 있어서 내피세포는, 내피세포 자체가 관을 이룰 만큼 충분한 증식(proliferation)을 하고, 성장한 세포는 방향성 을 가지고 공간적인 배열(migration)을 한다고 알려져 있다 [10,11]. 따라서 본 연구에서는 fucoidan 처리 후 wound healing 에 대한 효과를 확인하였다. 세포를 6 well plate에 $2 \times 10^{5}$ cells/well의 농도로 세포를 접종하고, $37^{\circ} \mathrm{C}, 5 \% \mathrm{CO}_{2}$ incubator 에서 24 시간 동안 배양 후, 마이크로 피펫의 blue tip을 사용하 여 plate 중간에 scratch를 형성시켰다. Scratch로 인해 부유된 세포는 세척하여 제거하고, $1 \mu \mathrm{g} / \mathrm{mL}$ fucoidan (with or without $10 \mathrm{ng} / \mathrm{ml} \mathrm{FGF2)}$ 이 포함된 serum free media로 채워주었다. 이후 48 시간 동안 배양 후, 세포의 이동능력을 현미경을 이용하 여 분석하였다.

\section{6. 역전사 중합효소 연쇄반응}

Fucoidan 처리를 통해 변화되는 cytokine의 mRNA 수준을 확인하고자 다음과 같이 진행하였다. 6 well에 $3 \times 10^{5}$ cells/well 농도로 세포를 접종시키고, $37^{\circ} \mathrm{C}, 5 \% \mathrm{CO}_{2}$ 배양기에 넣어 24 시 간 동안 배양하였다. 이 때, $1 \mu \mathrm{g} / \mathrm{mL}$ fucoidan (with or without $10 \mathrm{ng} / \mathrm{mL}$ FGF2)가 포함된 media로 change해주고, 24시간, 48시간 그리고 96시간 경과에 따라 RNA 를 추출하였다. 그런 후, total RNA preparation (GeneAll, Seoul, Korea) 단계를 거 
쳐 two step reverse transcriptase polymerase chain reaction kit (Intron Biotechnology, Gyeonggi-do, Sungnam, Korea) 를사용하여 $\mathrm{CDNA}$ 를 합성하였다. 합성된 $\mathrm{CDNA}$ 를 template 삼아 신생혈관생성 와 관련된 VEGF-A의 Forward/Reverse primer (Forward: 5'-GGGCAGAATCATCACGAAGT-3', Reverse: 5'-TGGTGATGTTGGACTCCTCA-3'), MMP9의 Forward/Reverse primer (Forward: 5'-ACCTCGAACTTTGACAGCGACA-3', Reverse: 5'-GATGCCATTCACGTCGTCCTTA-3'), ICAM-1의 Forward/Reverse primer (Forward: 5'-CAGAGGTTGAACCCCACAGT-3', Reverse: 5'-CCTCTGGCTTCGTCAGAATC-3') 그리고 STAT3의 Forward/Reverse primer (Forward: 5'-TCTGGGTCTGGCTGGACAAT-3', Reverse: 5'-TTAGCAGGAAGGTGCCTGGA-3') 를 사용하여 RT- PCR 진행 후, 전기영동을 통하여 증폭산물을 확인하였다.

\section{7. 통계 처리}

각 실험은 3회 이상 반복 실험을 수행하였으며, ANOVA Student t-test를 행하여 각 시험군의 평균과 표준편차를 산출 하였고, 각 시험군 간의 유의성을 $p<0.05$ 수준에서 검증하였다.

\section{결 과}

\section{Fucoidan이 세포 성장에 미치는 영향}

HUVECs에서 FGF2와 fucoidan을 동시 처리하였을 때 세포 성장에 미치는 영향을 확인하였다. 내피 세포의 혈관 형성에 있 어서, 내피세포 자체는 관을 이룰 만큼의 충분한 증식(proliferation)을 필요로 하기 때문에[11,12], 먼저, 세포 성장에 대한 fucoidan의 효과를 확인하고자 세포 성장률을 측정하였다. 세 포의 성장은 $10 \mathrm{ng} / \mathrm{mL}$ FGF2 단독 처리보다, $1 \mu \mathrm{g} / \mathrm{mL}$ fucoidan, $10 \mu \mathrm{g} / \mathrm{mL}$ fucoidan를 처리했을 때 유의성 있는 증가를 보였다. 또한, FGF2 단독 처리, fucoidan 단독 처리보다, FGF2와 fucoidan을 함께 처리 했을 때, 세포 성장은 2.5배 이상 유의성 있는 증가를 보였다(Table 1).

\section{2. 신생혈관생성 확인을 위한 tube formation assay}

Fucoidan에 의한 신생혈관생성 효과를 평가하기 위해 Matrigel 을 이용한 미세관형성 정도를 평가하였다. 실험의 결과에서 보 여지듯, fucoidan $(1 \mu \mathrm{g} / \mathrm{mL})$ 단독 처리만으로 뚜렷한 미세관형 성이 증가하는 경향을 보였다 $(p<0.05)$. 그러나 미세관 형성은 FGF2 $(10 \mathrm{ng} / \mathrm{mL})$ 와 fucoidan $(1 \mu \mathrm{g} / \mathrm{mL})$ 를 동시 처리 했을 경 우 대조군에 비하여 튜브형성 정도가 약 2.8 배 유의성 있는 증가 를 보였다(Figure 1A and B). 이러한 결과는 fucoidan과 FGF2 의 동시처리는 상호간의 신생혈관 생성효과에 시너지 효과를 보였다.

\section{3. 세포이동능 평가를 통한 신생혈관 생성활성}

신생혈관 활성 효능을 평가하기 위하여 세포의 이동 활성을 평가하였다. 대조군은 약 $10 \%$ 정도의 세포이동을 보였으나 FGF2 경우 약 23\% fucoidan 21\% 정도 세포의 이동이 관찰되 었다. 또한 이들은 fucoidan 와 FGF2를 동시 처리 했을 때, 세포 의 이동이 $64 \%$ 정도로 유의성 있게 증가함이 관찰되었다 (Figure 2B).
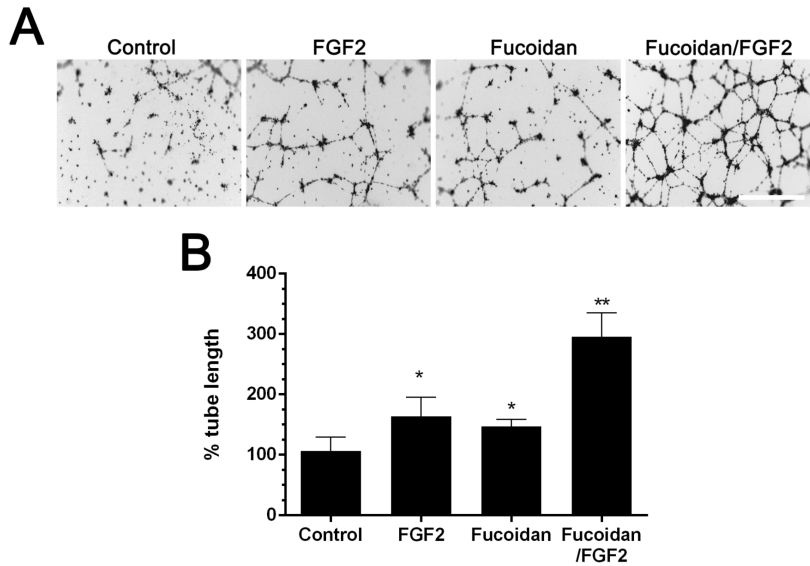

Figure 1. Fucoidan enhances FGF2 tubular morphogenesis by fucoidan in Martrigel (A) and calculated total length (B). Vascular tube formation by HUVEC treated with or without at $10 \mathrm{ng} / \mathrm{mL}$ FGF2, in the absence or in the presence of fucoidan at $1 \mu \mathrm{g} / \mathrm{mL}$.

Table 1. Effect of the fucoidan on FGF2 induced HUVEC proliferation

\begin{tabular}{lcccccc}
\hline FGF2 $(\mathrm{ng} / \mathrm{mL})$ & - & 10 & - & - & 10 & 10 \\
Fucoidan $(\mu \mathrm{g} / \mathrm{mL})$ & - & - & 1 & 10 & 1 & 10 \\
Fold change & 1 & $1.30 \pm 0.01^{\star}$ & $1.37 \pm 0.06^{*}$ & $2.03 \pm 0.09^{\star}$ & $1.56 \pm 0.13^{\star}$ & $2.58 \pm 0.06^{\star}$ \\
\hline
\end{tabular}

HUVEC were treated with $10 \mathrm{ng} / \mathrm{mL}$ FGF2, with or without fucoidan. Fucoidan treated with FGF2, has synergetic effect on cell proliferation. Results are the mean \pm SD of three determinations ( ${ }^{\star} p<0.05$ vs. untreated control).

Abbreviation: FGF2, fibroblast growth factor2. 

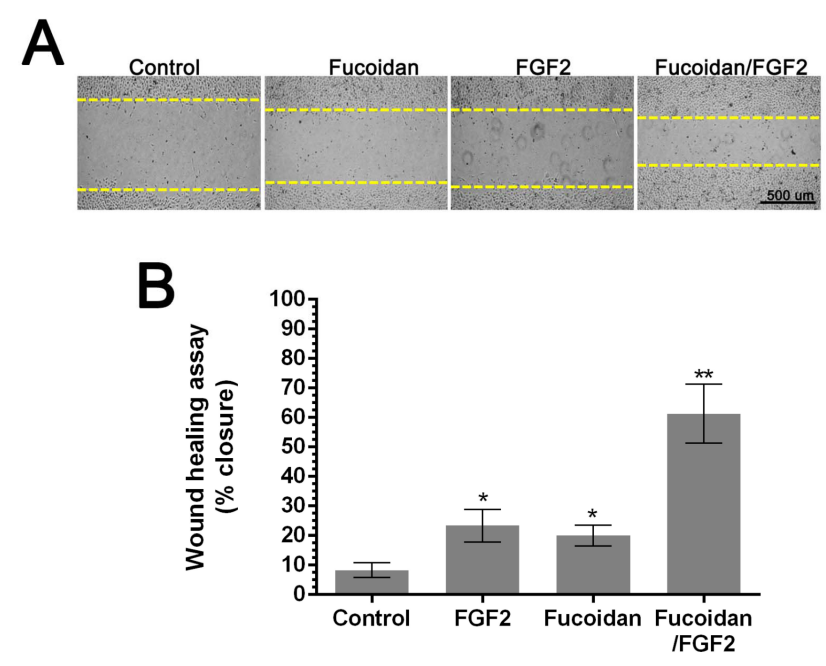

Figure 2. Fucoidan enhances FGF2 induced HUVEC migration. In vitro wound healing assay image (A) and quantitative closure percentage (B) was performed to evaluate the migration abilities of HUVECS treated with FGF2 in the absence or presence of fucoidan.

\section{Fucoidan/FGF2의 처리에 의한 유전자의 발현 평가}

Fucoidan/FGF2를 동시 처리하였을 경우 신생혈관생성과 관련된 유전자의 발현 변화량을 평가하기 위하여 RT-PCR을 수 행하였다. 본 연구에서는 Fucoidan/FGF2 처리 48시간 후에 시 점에서 STAT3, VEGF-A 그리고 ICAM-1의 mRNA 발현 수준이 증가하였으며, 96시간 경과 후에 MMP9 의 mRNA 발현량이 유 의성 있게 증가됨을 보였다(Figure 3). 이러한 결과는 fucoidan/FGF2의 처리에 의한 신생혈관 증진효과는 STAT3, VEGF-A, ICAM-1, 및 MMP9의 mRNA 발현과 상관성을 보였다.

\section{고 찰}

신생혈관생성은 기관의 형성과 발달에 매우 중요한 역할을 한다. 신생혈관 생성에 대한 효과에 대하여 몇 몇 연구자들은 fucoidan의 효과를 보고한바 있으나[4,12,13] 이와 관련된 분 자적 수준에서의 관련 연구는 미흡하다. 따라서 본 연구에서는 혈관내피세포를 이용하여 fucoidan과 FGF2 성장인자에 따른 신생혈관생성 효과를 평가하고 그에 따른 관련 유전자 발현 변 화를 평가하였다. Matou 등[4]은 fucoidan이 FGF2와의 혼합 효과를 검증하기 위하여 $0.1 \sim 10 \mu \mathrm{g} / \mathrm{mL}$ 의 fucoidan 농도에서 평가하였으며, 미세관 형성률에 있어 $1 \mu \mathrm{g} / \mathrm{mL}$ 과 $10 \mu \mathrm{g} / \mathrm{mL}$ 의 후코이단이 처리에서만 유의성 있는 증가를 보였다. 이에 본 연 구에서는 fucoidan이 HUVECs의 세포성장에 미치는 영향을 평가하기 위하여 초기 $1 \mu \mathrm{g} / \mathrm{mL}$ 과 $10 \mu \mathrm{g} / \mathrm{mL}$ 의 농도를 기준으

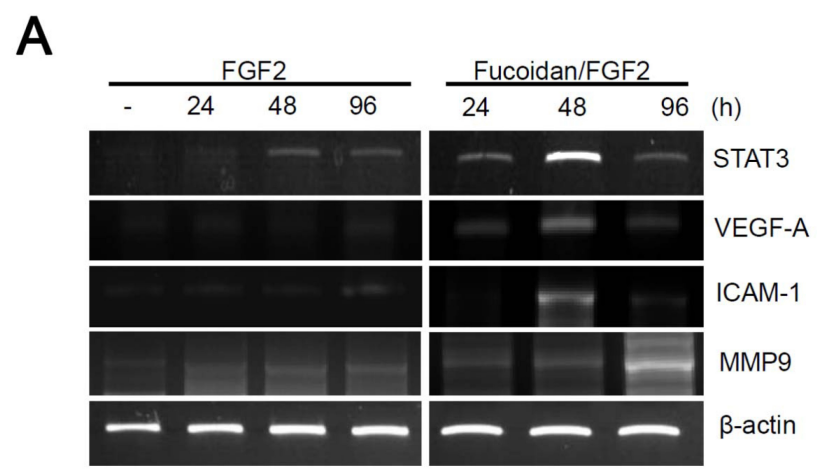

B
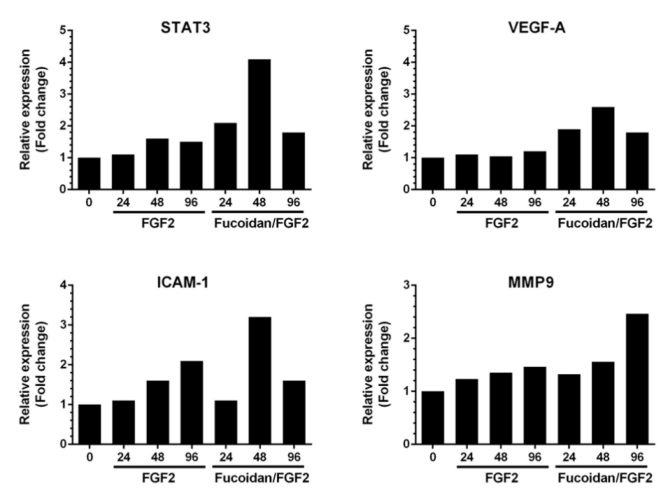

Figure 3. Fucoidan treatment enhances cytokine production of HUVECs. Cells were treated with $1 \mu \mathrm{g} / \mathrm{mL}$ fucoidan showed increased level of angiogenic factor compared to untreated cells. The expressions of angiogenic factor were analyzed by RT-PCR (A). The relative band intensities of detected agarose gel image was quantified using ImageJ (https://imagej.nih.gov/ij) program (B).

로 실험하였다. 본 연구의 결과에서 세포의 성장은 fucoidan의 농도가 증가함에 따라 증가하는 경향을 보였다. 비록 본 연구에 서는 fucoidan 이 HUVECs 의 세포성장에 어떠한 기전을 통해 증식을 유도하는지에 대하여 연구하지 않았지만, 이러한 결과 는 Zemani 등[13]의 선행연구 결과와 유사하였다. 또한 fucoidan이 FGF2에 의한 HUVECs 의 angiogenic 활성에 미치는 영향을 평가하기 위하여, 미세관 형성과 세포이동 분석을 수행 하였다. Matou 등[4]은 작은 분자량의 fucoidan 분획물이 FGF2에 의해 유도되는 혈관형성 활성을 더욱 촉진한다고 보고 하였다. 반면 Soeda 등[7]의 연구에 의하면 큰 분자량을 가진 fucoidan 은 오히려 FGF2에 의해 유발된 관 형성을 억제한다고 보고하였다. 본 연구에서는 분자량을 분획하지 않은 저분자량 과 고분자량이 혼합되어있는 fucoidan을 사용하여 실험하였으 며, 신생혈관 생성 활성은 Matou 등[1]이 보고한 결과 같은 혈 관신생의 증가 효과를 보였다. 이러한 효과는 비록 사용된 fucoidan이 저분자량과 고분자량이 혼합되어 있기는 하지만 
이들 중에서 저분자량에 의한 효과라고 생각되며 Matou 등[4], 이러한 분자량 크기 이외에도, 서로 다른 추출원 및 추출 방법 등 에 기인할 할 수 있을 것이라고 생각된다. 신생혈관생성 과정에 는 다양한 유전자들이 관여하고 있다. 본 연구에서는 신생혈관 생성에 변화가 예상되는 중요 신생혈관인자들인 VEGF-A, ICAM-1, MMP9 그리고 STAT3를 대상으로 mRNA 발현변화를 평가하였다. VEGF-A는 혈관내피세포의 유사 분열 물질 및 다 양한 생리학적 및 병리학적 조건에서 혈관 신생의 중요 조절인 자로 알려져 있다[14]. VEGF-A는 VEGFR에 결합하여, tyrosine 인산화를 유발하고 내피 세포의 분화, 성장, 생존 그리고 이동을 유도한다[15-17]. 그리고 ICAM-1 (intercellular adhesion molecule 1)은 일반적으로 내피 세포에서 발현되는 세포 표면 당 단백질의 하나로서 신생혈관생성과 관련된 기능에 중요한 역할을 한다고 보고 되어있다[18]. 특히, 이러한 ICAM-1의 발 현은 VEGF-A 및 FGF2 등에 의하여 증가 된다는 보고가 있다 [19,20]. 또한 젤라틴 B로 알려진 MMP9는, 구조 조정 및 신생 혈관생성 동안 ECM (extracellular matrix) 및 기저막 분해에 중요한 역할을 하는 것으로 알려져 있다[21]. 이와 더불어 전사 의 신호 변환과 활성자인 STAT3도 신생혈관생성에서의 세포의 생존, 증식, 분화 그리고 발암화에 중요한 역할을 하는 것으로 보고되어 있다[22,23]. 본 연구의 결과에서 fucoidan/FGF2 처 리에 의한 신생혈관 효과의 증가와 함께 VEGF-A, ICAM-1, $\mathrm{MMP}$ 9 그리고 STAT3의 유전자 발현량을 평가한 결과 FGF2 단 독에 의한 것에 비교하여 이들의 유전자 발현율이 Fucoidan/FGF2 에 의해 증가되었다. 특히 STAT3, VEGF-A, ICAM-1은 fucoidan/FGF2 처리에 의해서 48 시간에 mRNA 발현율이 최 대가 되었으며 이는 다시 96 시간에 감소되는 양상을 보였다. 이 러한 것은 FGF2의 짧은 반감기[2] 때문에 활성도가 감소 되었 기 때문이라 추정된다. 반면 MMP9은 이들 유전자와 다르게 시 약처리 후96시간에 높은 발현율을 보였다. 이러한 시간적 차이 는 MMP9이 하위 신호 전달 기전[24]에서 발현양상이 조절되는 것으로 유추된다.

이러한 결과들은 fucoidan/FGF2 의 처리에 의한 신생혈관 생성 효과에 있어 이들 유전자가 관련되어 있음을 확인 할 수 있 었다. 향후 이러한 유전자들의 발현이 fucoidan/FGF2에 의한 신생혈관 형성 촉진에 직접적인 영향을 미치는 지에 대한 신호 전달기전 연구가 추가적으로 이루어져야 할 것으로 생각된다.

\section{요 약}

신생혈관생성은 여러 신생혈관 생성 인자들이 포함되는 중
요한 과정이며, 특히 이 과정에서는 섬유아세포증식인자(FGF-2) 는 세포의 증식률과 미세관 형성을 촉진하기 때문에 중요한 신 생혈관 생성인자로 여겨진다. 최근 연구에 따르면 해조류에서 추출되는 후코이단 다당류 물질이 섬유아세포 증식인자2에 의 한 혈관내피세포의 미세관형성을 더욱 촉진한다고 보고하였 다. 그러나 섬유아세포 증식인자와 후코이단 복합처리에 따른 신생혈관생성 활성에 대한 분자적 메카니즘은 아직 연구가 부 족하다. 따라서 본 연구에서는 신생혈관생성 활성을 알아보기 위하여 섬유아세포 증식인자와 후코이단 물질의 복합처리에 따 른 세포의 증식과 미세관형성률 그리고 세포의 이동율을 측정 하였다. 또한 이들의 신생혈관 생성 활성에 관련된 인자를 탐색 하기 위하여 VEGF-A, ICAM-1, MMP9, 그리고 ICAM-1 유전 자를 연전사 중합연쇄반응으로 평가하였다. 본 연구의 결과에 서는 후코이단과 섬유아세포 증식인자 복합처리는 혈관내피세 포의 성장률, 미세관 형성률 그리고 세포의 이동률을 촉진하고, 이 과정에서 신생혈관생성 기능과 관련된 STAT3, VEGF-A, MMP9 그리고 ICAM-1의 유전자 발현을 촉진함으로 신생혈관 생성활성이 나타나는 것으로 보여진다. 그러나 이러한 유전자 발현이 fucoidan/FGF2에 의한 angiogenic 활성 촉진에 직접 적인 영향을 미치는 지에 대한 추가적인 연구가 이루어져야 할 것으로 생각된다.

Acknowledgements: This paper was supported by Wonkwang Health Science University in 2017.

Funding: None

Conflict of interest: None

\section{REFERENCES}

1. Carmeliet P, Jain RK. Angiogenesis in cancer and other diseases. Nature. 2000;407(14):249-257.

2. Folkman J, Cotran R. Relation of vascular proliferation to tumor growth. Int Rev Exp Pathol. 1976;16:207-248.

3. Yun YR, Won JE, Jeon E, Lee S, Kang W, Jo H, et al. Fibroblast growth factors: biology, function, and application for tissue regeneration. J Tissue Eng. 2010;218142.

4. Matou S, Colliec-Jouault S, Galy-Fauroux I, Ratiskol J, Sinquin C, Guezennec J, et al. Effect of an oversulfated exopolysaccharide on angiogenesis induced by fibroblast growth factor-2 or vascular endothelial growth factor in vitro. Biochem Pharmacol. 2005;69(5):751-759.

5. Liu F, Wang J, Chang AK, Liu B, Yang L, Li Q, et al. Fucoidan extract derived from Undaria pinnatifida inhibits angiogensis by human umbilical vein endothelial cells. Phytomedicine. 2012;19(8-9):797-803. 
6. Koyanagi S, Tanigawa N, Nakagawa H, Soeda S, Shimeno H. Oversulfation of fucoidan enhances its anti-angiogenic and antitumor activities. Biochem Pharmacol. 2003;65(2):173-179.

7. Soeda S, Kozako T, Iwata K, Shimeno H. Oversulfated fucoidan inhibits the basic fibroblast growth factor-induced tube formation by human umbilical vein endothelial cells: it's possible mechanism of action. Biochim Biophys Acta. 2000;1497(1): 127-134.

8. Manzo-Silberman S, Louedec L, Meilhac O, Letourneur D, Michel JB, Elmadbouh I. Therapeutic potential of fucoidan in myocardial ischemia. J Cardiovasc Pharmacol. 2011;58(6): 626-632.

9. Matou S, Helley D, Chabut D, Bros A, Fischer AM. Effect of fucoidan on fibroblast growth factor-2-induced angiogenesis in vitro. Thromb Res. 2002;106(4-5):213-221.

10. Beck L Jr, D'Amore PA. Vascular development: cellular and molecular regulation. FASEB J. 1997;11(5):365-373.

11. Risau W, Flamme I. Vasculogenesis. Annu Rev Cell Dev Biol. 1995;11:73-91.

12. Chabut D, Fischer AM, Helley D, Colliec S. Low molecular weight fucoidan promotes FGF-2-induced vascular tube formation by human endothelial cells, with decreased PAI-1 release and ICAM-1 downregulation. Thromb Res. 2004;113(1): 93-95.

13. Zemani F, Benisvy D, Galy-Fauroux I, Lokajczyk A, Colliec-Jouault S, Uzan G, et al. Low-molecular-weight fucoidan enhances the proangiogenic phenotype of endothelial progenitor cells. Biochem Pharmacol. 2005;70(8):1167-1175.

14. Ju M, Mailhos C, Bradley J, Dowie T, Ganley M, Cook G, et al. Simultaneous but not prior inhibition of VEGF165 enhances the efficacy of photodynamic therapy in multiple models of ocular neovascularization. Invest Ophthalmol Vis Sci. 2008;49:662670.

15. Lai CM, Spilsbury K, Brankov M, Zaknich T, Rakoczy PE. Inhibition of corneal neovascularization by recombinant ad- enovirus mediated antisense VEGF RNA. Exp Eye Res. 2002; 75(6):625-634.

16. Ferrara N, Davis-Smyth T: The biology of vascular endothelial growth factor. Endocr Rev. 1997;18:4-25.

17. Brown LF, Detmar M, Claffey K, Nagy JA, Feng D, Dvorak AM, et al. Vascular permeability factor/vascular endothelial growth factor: a multifunctional angiogenic cytokine. EXS. 1997;79: 233-269.

18. Carmona G, Chavakis E, Koehl U, Zeiher AM, Dimmeler S. Activation of Epac stimulates integrin-dependent homing of progenitor cells. Blood. 2008;111(5):2640-2646.

19. Radisavljevic Z, Avraham H, Avraham S. Vascular endothelial growth factor up-regulates ICAM-1 expression via the phosphatidylinositol $3 \mathrm{OH}$-kinase/AKT/Nitric oxide pathway and modulates migration of brain microvascular endothelial cells. J Biol Chem. 2000;275(27):20770-20774.

20. Presta M, Andres G, Leali D, Dell'Era P, Ronca R. Inflammatory cells and chemokines sustain FGF2-induced angiogenesis. Eur Cytokine Netw. 2009;20(2):39-50.

21. Muroski ME, Roycik MD, Newcomer RG, Van den Steen PE, Opdenakker G, Monroe HR, et al. Matrix metalloproteinase9/gelatinase $B$ is a putative therapeutic target of chronic obstructive pulmonary disease and multiple sclerosis. Curr Pharm Biotechnol. 2008;9(1):34-46.

22. Chen Z, Han ZC. STAT3: a critical transcription activator in angiogenesis. Med Res Rev. 2008;28(2):185-200.

23. Jekal SJ, Lee JA, Rho JS. Mast cells and vascular endothelial growth factor expression in neoangiogenesis of cervical intraepithelial neoplasia and invasive squamous cell carcinomas of the uterine cervix. Korean J Clin Lab Sci. 2005;37(3):197-206.

24. Xie T, Wei D, Liu M, Gao AC, Osman FA, Sawaya R, Huang S. Stat3 activation regulates the expression of matrix metalloproteinase-2 and tumor invasion and metastasis 2. Oncogene. 2004;23(20):3550-3560. 